Author manuscript

\title{
The potential of ecologically enhanced urban parks to encourage and catalyze densification in greyfield
}

suburbs J ulian Bolleter \& Cristina E. Ramalho

Australian Urban Design Research Centre, Faculty of Architecture, Landscape Architecture and

Visual Arts, The university of Western Australia, Level 2, 1002 Hay Street, Perth, WA 6000,

Australia, Phone: +61863186203

Published online: 30 Sep 2014.

To cite this article: J ulian Bolleter \& Cristina E. Ramalho (2014) The potential of ecologically enhanced urban parks to encourage and catalyze densification in greyfield suburbs, J ournal of Landscape Architecture, 9:3, 54-65, DOI: $10.1080 / 18626033.2015 .968418$

To link to this article: http:// dx.doi.org/ 10.1080/ 18626033.2015.968418 


\title{
The potential of ecologically enhanced urban parks to encourage and catalyze densification in greyfield suburbs
}

\author{
Julian Bolleter and Cristina E. Ramalho \\ The University of Western Australia, Australia
}

\begin{abstract}
This paper explores the potential of a strategy for achieving infill development in Australian greyfield suburbs in which redesigned, ecologically enhanced urban parks, in areas with reasonable access to public transport, are employed to encourage, catalyze, and ultimately support, residential densification. This process involves the upzoning of a walkable catchment of selected greyfield urban parks to higher residential densities than the market is currently delivering. To encourage this upzoning in the local community, local parks are redesigned using an ecological-oriented approach that seeks to enhance both their ecological and social values. The parks' redesign is likely to lead to an increase in land values, which, in turn, is anticipated to catalyze redevelopment. In combination with increased zoning densities, this strategy is hypothesized to lead to greater densification. It is proposed that, as the densification occurs, a needs-based assessment is conducted to determine the park equipment required by the increased park catchment population. The potential of this process is explored in an illustrative planning exercise in the local government area of Bayswater (Perth, Western Australia), which has significant infill targets and a large amount of sports field-dominated parkland. The paper concludes by arguing that a strategy of densification around public open space could potentially aid in greyfield suburbs achieving their infill targets, as well as lead to improved social and ecological outcomes.
\end{abstract}

Greyfield suburbs / ecological enhancement / public open space /

urban densification / urban nature / urban parks
Introduction

Urban sprawl is a major facet of contemporary urbanization. In countries such as the U.S. and Australia, expansive suburbanization consisting of single-family, freestanding residential development is ubiquitous (e.g., Schneider $\&$ Woodcock 2008). Despite its ubiquity, urban sprawl faces a number of emerging crises, which threaten its dominance. These include challenges in relation to peak oil, the destruction of agriculturally productive (e.g., Seto et al. 2000) and biodiverse land (e.g., Radeloff et al. 2010), ballooning infrastructure costs and commuting times (Brownstone $\mathcal{E}$ Golob, 2009; Bento et al. 2005), and the concentration of economic and social vulnerabilities on the cities' fringes (Dodson \& Sipe 2008; Zhao \& Kaestner 2010; Sturm \& Cohen 2004; Nechyba \& Walsh 2004).

So, to mitigate the impacts of urban sprawl, there is an increasing emphasis placed on achieving residential urban infill development in many cities around the world. In Australia, for example, capital city planning policies stipulate that 60 percent of all new residential development should be infill. Nevertheless, only 30 percent is currently being achieved. This deficit can be explained by a number of factors, such as typically unplanned approaches to infill development and community resistance (the NIMBY factor). [1] Given that Australia's population is projected to grow significantly in the next few decades (Australian Bureau of Statistics 2011), this existing shortfall in meeting infill targets, if continued, will be seriously compounded over time. On a regional scale, the failure of cities to meet their respective infill targets means that they will continue to grow in what is recognized as a typically unhealthy, costly, unsustainable, and unproductive manner (Dodson \& Sipe 2008; Kelly et al. 2011; Newman et al. 2009; Western Australian Department of Planning 2010; Nechyba \& Walsh 2004; Sturm \& Cohen 2004).

In pursuit of infill development, urban planning strategies have focused primarily on Transport Orientated Development (TOD) principles (Calthorpe \& Fulton 2001), which include 'activity centres', and the possibility of increased residential density along major road corridors (DuckworthSmith 2012; City of Melbourne 2010; Woodcock et al. 2010). [2] While the principles of TOD are well established and have validity, it is our belief that for cities to be resilient we need a greater range of strategies for achieving the required infill development. 
To date, and to our knowledge, the potential advantages of enhancing the ecological value of existing urban parks in Australian greyfield suburbs (middle ring suburbs) as a way to encourage residential densification has not been researched. In this study, we hypothesize that the employment of an ecological approach in the redesign of urban parks of greyfield suburbs (served with reasonable access to public transport) may uplift the real estate value of adjacent areas, which can then encourage redevelopment. In conjunction with increased residential zoning, this should enable greater residential densification. We also hypothesize that the redesign of urban parks towards greater naturalness, [3] ecological function, and diversity of active and passive recreational uses they can cater for, offers an incentive for residents to support well-designed infill development at higher densities than those currently being achieved. In this context, the paper's main research question is: How can the redesign of parks in greyfield suburbs be employed to encourage and support residential densification?

Redesigning urban parks using an ecological or ecosystem design ap proach recognizes the complex interactions between physical, biological, and social aspects of landscape planning and design (Gobster 2001). Such an approach seeks to enhance parks' ecological values, increasing native bio-diversity, habitat availability, and promoting ecosystem functioning. Equally important, it accommodates the diverse cultural values of the local community and place, the values and expectations people hold toward urban parks, and the community needs (Hunter $\mathcal{E}$ Hunter 2008; Gobster et al. 2007; Gobster 2001; Thompson 2002). An ecological approach to the design of urban parks recognizes that ecologically driven interventions can only be sustainable if they are aesthetically pleasing and accepted by local users. Furthermore, and importantly, such an approach recognizes the potential of large urban parks to be more than simple 'urban green spaces'. Such parks can enhance landscape connectivity and be stepping stones in regional green networks across metropolitan regions, thus contributing to local and regional biodiversity; they can provide a much wider range of ecosystem services than standard sports field parks; and, most importantly, they can bring the experience of nature and nature education to urban dwellers (Gobster 2001).

First, we discuss the rationale for redesigning urban parks as a strategy to promote densification in greyfield suburbs. Importantly, we review the benefits of interacting with nature in urban areas and how urban parks designed using an ecological approach outperform sports field parks in the provision of ecosystem services, as well as in social and ecological benefits. Second, we review the evidence suggesting the public's preferences for parks with a more naturalistic composition over sports field parks and how the former can have an uplifting effect in the real estate values of adjacent areas. Third, we outline a process by which densification could be achieved adjacent to parks in greyfield suburbs. This process is proposed via an illustrative planning exercise in the local government area of Bayswater (Perth, Western Australia), which is typical of the greyfield suburbs of Australian capital cities (Fig. 1)
The rationale for densification around redesigned urban parks in greyfield suburbs

Greyfield suburbs

Greyfield suburbs have been defined by Newton et al. (2010) as middle ring suburbs of the main capital Australian cities comprising underutilized and outdated property assets, and where the residential building stock is failing. [4] These residential areas generally consist of privately owned sites and were developed between the 1950 and 1970 (Newton et al. 2011). Given their relative proximity to the city centres and redevelopment potential, greyfield suburbs typically have high infill development targets (Western Australian Department of Planning 2010). Nevertheless, densification in these greyfield suburbs often faces considerable community resistance. In fact, a survey revealed that across all Australian capital cities, 52 percent of suburban residents 'would not like' increased population in their neighbourhood and only 11 percent said they would like it (Productivity Commission 2011). In greyfield suburbs, the former attitude is accentuated by the fact that residents often feel they are denied a real say in how their neighbourhood develops and, therefore, often oppose all changes (Kelly et al. 2011). This attitude is further compounded by poorly executed examples of densification from the 1970s (Duckworth-Smith 2009), which created a poor public perception of higher density residential living.

Greyfield parks

While Perth's greyfields suburbs contain a reasonable amount of public open space, much of this is undesigned, offers minimal amenity, and typically is underutilized. Indeed, this ubiquitous component of the greyfield landscape comprises parks of various sizes that are typically simply turfed, sometimes with scattered trees. Moreover, organized active team sports, over many other possible community and ecosystem services (for example, passive recreation and wildlife habitat), are predominant in the design of greyfield parks. Among Perth's greyfields parks greater than 1 hectare in size, only 32 percent have a 'diversity of planted species', only 20 percent have wildlife, and only 4 percent have wetlands, despite the fact that, historically, Perth was a city of wetlands (Centre for the Built Environment and Health 2013). Furthermore, 85 percent of those greyfield parks have an ubiquitous underlay of reticulated turf, 35 percent have no walking paths, 76 percent have poorly shaded or completely exposed paths, and, in general, there are more parks with ovals ( 152 in total) than those with either BBQ or picnic facilities-59 and 9, respectively (Centre for the Built Environment and Health 2013). As a consequence of the simplified environment and design, the greyfield parks offer little in ecological and, to a degree, social terms. Furthermore, they consume increasingly valuable resources, such as water (Grose 2010), fertilizer, and energy (Fig. 2).

The focus on active sports in parks is the result of the 'recreation movement' (Sipe E Byrne 2010), which was prevalent in the mid-twentieth century, when Australia's greyfields grew significantly. The recreation movement proposed that "what were needed most were opportunities for citizens to exercise, to strengthen and discipline bodies, to temper immoral impulses, and to give people a place to vent frustrations and escape from urban life' (Sipe E Byrne 2010). This movement saw the cutting back of highly wrought landscaped parks of the nineteenth and early twenti- 
eth centuries, so as to resemble sports fields. The parks of Perth's greyfields suburbs are typical of the recreation movement, having little vegetation, large areas of irrigated lawns, and facilities designed to support team sports, such as clubrooms, goal posts, and cricket pitches (Sipe $\mathcal{E}$ Byrne 2010).

The benefits of ecologically enhanced urban parks

The dominance of ecologically barren urban parks in greyfield suburbs occurs in spite of a significant body of literature concerned with the multiple benefits of living nearby and interacting with nature in urban areas. [5] Indeed, exposure to nature provides several well-being and health benefits to urban dwellers (Mead et al. 2006; Keniger et al. 2013; Tzoulas et al. 2007). Importantly, nature has a restorative function, enhancing health recovery (Ulrich 1984) and perceived good health (Chiesura 2004), encouraging physical activity and the use of outdoor spaces (Humpel et al. 2002), increasing social integration and interaction (Coley et al. 1997), reducing stress, enhancing contemplation, and providing a sense of peacefulness and tranquillity (Chiesura, 2004). Other important ecosystem services provided by nature that are crucial for the liveability of modern cities, include microclimatic amelioration and mitigation of climatic extremes, sequestration of air pollutants, flood mitigation, and stormwater attenuation (Wong 2006; Tzoulas et al. 2007; Bolund $\mathcal{E}$ Hunhammar 1999; Jim $\mathcal{E}$ Chen 2009). Also, as people increasingly live further away from the natural areas outside city boundaries, engagement with urban remnant ecosystems, as well as with elements of the native flora and fauna present in urban parks and other public open spaces, prevents the extinction of nature's experience (Miller 2005) and fosters the development of a sense of place and duty of care for the environment (Dunn et al. 2006; Uzzell et al. 2002). Finally, these green spaces embedded in the urban matrix can have a major importance for biodiversity conservation, providing habitat and landscape connectivity for numerous fauna and flora species (e.g., Koh $\&$ Sodhi 2004; Ramalho et al. 2014).

Urban parks, however, vary in their level of naturalness and human modification, from including a high proportion of remnant vegetation, wetlands, or riparian habitats, to being highly modified and reduced to lawns. Increasingly, there is evidence that urban parks that are more ecologically diverse and have higher perceived naturalness provide greater ecological and social benefits. For example, the diversity of habitats, including the presence of lakes and wetlands, contributes significantly to the perceived well-being benefits of urban parks to their users (Fuller et al. 2007; Luttik 2000). Furthermore, this restorative effect also increases with perceived species richness among certain biodiversity groups, including plants and birds (Fuller et al. 2007; Dallimer et al. 2012). In fact, in a study undertaken in fifteen green spaces in Sheffield, UK, Fuller et al. (2007) found that perceived species richness was even more important to park visitors' well-being than the park's size. Also, trees, and to a lesser extent other woody vegetation, are more efficient in the provision of several ecosystem services than herbaceous plants (Breuste et al. 2013). Indeed, while all vegetation can generally lower high temperatures due to evapo-transpiration, trees can contribute remarkably to climate regulation, as well as to the reduction of cooling and heating energy use, through shading in summer and reduction of wind speed in winter. Moreover, as air filtering increases with plant leaf area, trees generally have greater ability in the provision of this ecosystem service than other plant forms. Finally, from a biodiversity conservation perspective, urban parks that retain a significant amount of remnant vegetation, or that are vegetated with a diversity of native plants, have higher conservation value (Koh \& Sodhi 2004; McFrederick \& LeBuhn 2006).

Ecologically enhanced parks, individual preferences, and real-estate value trends

Recognition of the benefits of living nearby a good-quality public open space is increasingly reflected in individual preferences and real-estate value trends. Indeed, studies using hedonic valuation techniques, which are able to estimate the influence of the locality and house attributes on housing market prices, have provided evidence that suburban residents are willing to pay higher prices for houses adjacent to parks with greater naturalness (e.g., Crompton 2005; Lutzenhiser \& Netusil, 2001). As an illustration, the economists Lutzenhiser and Netusil (2001) found that in Portland, U.S., parks with more than 50 percent of their area covered with remnant vegetation, and that were used mostly for biodiversity conservation and natural resource-based recreation, had, on average, the largest positive effect on a home's sale price within a 450 metre radius of the park. In contrast, parks with more than 50 percent of their area manicured or landscaped, and that were designed for non-natural resource-dependent recreation (for example, ball fields and sports courts), had the lowest positive effect on property values surrounding the open space.

This uplifting effect in real estate value by ecologically enhanced parks, rather than sports field parks, has also been observed in Perth. Indeed, Pandit et al. (2013) found that urban parks with generous tree cover and a diversity of habitats, including wetlands, exerted a significant positive effect on the surrounding real estate values. They conclude that, on average, propriety price premiums increased by AU $\$ 14,500$ for a 10 percent increase in tree canopy cover on adjacent public open space (Pandit et al. 2013). In contrast, they found that sports field parks in Perth can exert a minimal negative impact on the surrounding property prices (Pandit et al. 2013). This reflects the low amenity provided by these public open spaces, but also the perceived inconveniences of living near them, in terms of car parking, noise, and lighting issues. Importantly, a recent survey of housing preferences in Perth, 'The Housing We'd Choose' (Curtin University \& Hames Sharley 2013), found that 90 percent of respondents ranked a dwelling's proximity to a park as a 'very important' or 'important' dwelling attribute. [6] In contrast, only 24 percent of the respondents considered it important to be near a sports field. In short, most residents would not trade higher density living for easy access to these parks.

In Perth, a preference for parks with more naturalistic compositions appears to increase in correlation with higher residential densities. Indeed, Syme et al. (2001) found that residents of 400 small lot developments (50o square metres or less in area) did not visit local parks any more than residents of larger lots (of 700 square metres or more). However, the former group of residents visited local wetlands more often (Syme et al. 2001). The broad conclusion that can be drawn from this research is that in Perth's higher density areas, people tend to seek out what they perceive to be more natural urban parks over sports field parks. [7] This resonates with the substantial body of literature concerning the psychological benefits of access to nature in the city (Ward Thompson 2002). 
Figure 1 Perth's greyfield suburbs and the local government area of Bayswater. Given their relative proximity to the city centre and redevelopment potential, greyfield suburbs typically have high infill development targets.

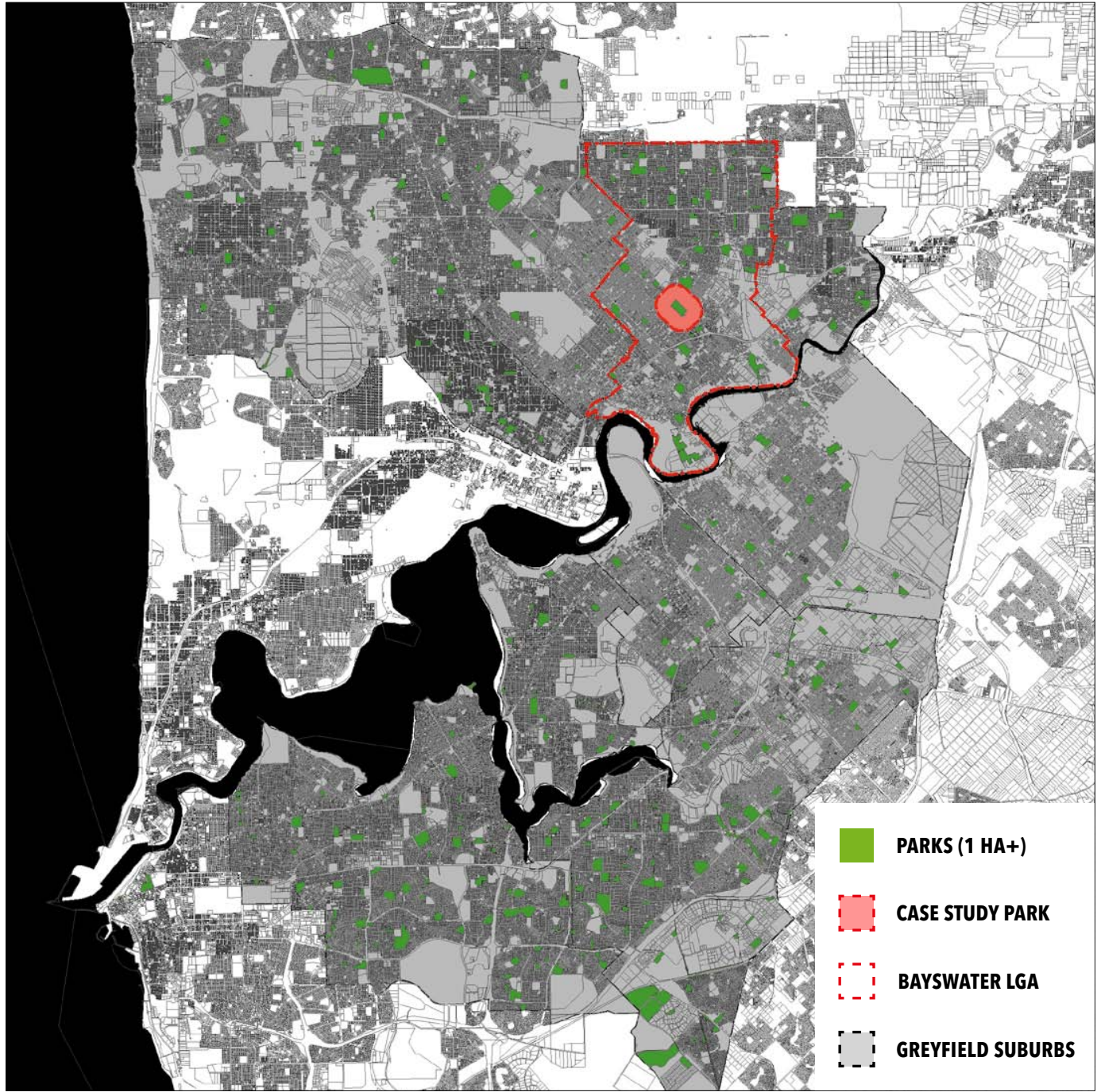

The potential of redesigning urban parks to encourage and catalyze densification

Given prevailing community preferences, redesigning urban parks using an ecological approach could be an avenue to raising real estate values in suburban areas surrounding main parks (Crompton 2005; Lutzenhiser \& Netusil 2001; Pandit et al. 2013). Increases in land values should stimulate redevelopment (Pracsys 2012; Newton et al. 2011), which, in combination with increased residential zoning densities, should enable greater residential densification. In part, the stimulation of redevelopment is explained by the Index of Property Redevelopment Potential (PRPI). The PRPI indicates that by increasing the value of a parcel of land in relation to the value of the house (which Pandit et al. 2013 indicate will result from the park's upgrade), redevelopment is encouraged (Newton et al. 2011). Furthermore, uplifted property values and redevelopment will, in turn, generate council rates increases, land taxes, increased stamp duty revenue, and developer contributions (Pracsys 2012), which will flow to local and state governments, and could subsequently be directed to the further reconfiguration and maintenance of parks. [8] Furthermore, and importantly, the redesign from relatively unpopular sports field parks (Curtin University \& Hames Sharley 2013; Pandit et al. 2013) to ecologically enhanced parks should also act as an incentive for local communities to actually support residential densification. [9] The presumption being that if a local community can see a benefit for densification they are more likely to support it (Kelly et al. 2011).
The ecological enhancement of urban parks as a strategy to encourage densification-an illustrative planning strategy

Here, we describe the main steps of the process by which the redesign of parks can be used to encourage and catalyze urban densification. We describe the process using an illustrative planning strategy in the local government area of Bayswater (Perth, Western Australia). Bayswater is located 6 kilometres northeast of Perth's central business district (Fig. 1) and has an infill development target of 8,500 dwellings (or approximately 19,550 people) by 2031 (Western Australian Department of Planning 2010).

\section{Park selection}

We suggest that parks to be redesigned and their surrounding areas targeted for urban densification should have reasonable access to public transport. We consider that 'reasonable access' can be understood as being within 1,400 metres, which equates to either a five minute bike ride or just less than a twenty minute walk to train stations (Fig. 3). [10] Of course, what can be considered reasonable access will vary across different segments of the community. [11] We have, for the purposes of this study, selected parks greater than 1 hectare in area. In Perth, these include neighbourhood open spaces and district open spaces, as defined by the Western Australian Department of Sport and Recreation (2012). While parks smaller than 1 hectare in size could support some adjacent densification, they are unlikely to contribute significantly to overall densification targets and, as such, are not the scope of this paper. 


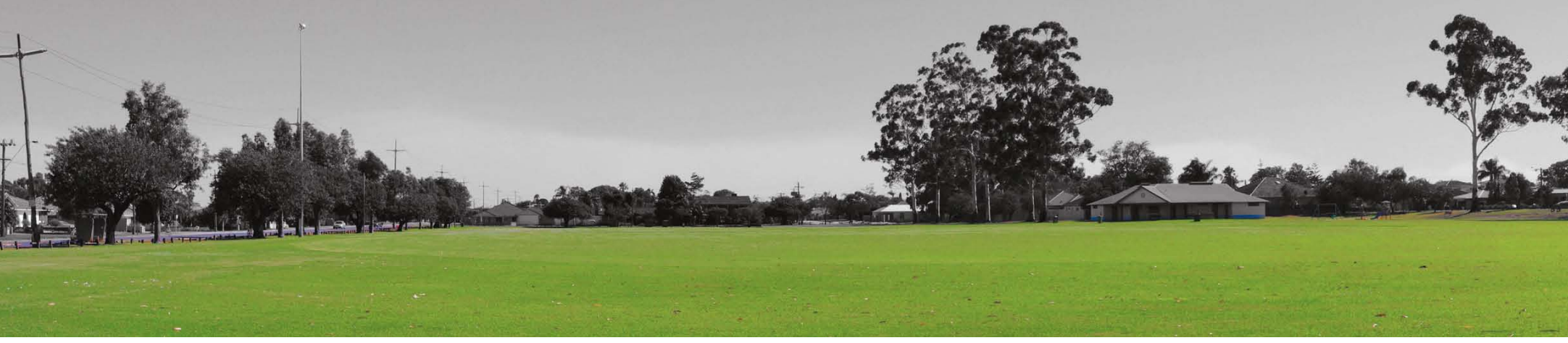

Figure 2 A typical greyfield park. With the exception of scattered trees, the simplified environment and design of a typical greyfield park offers little in ecological terms.

This spatial 'projective design' exercise focuses on Hillcrest Park (5 hectares) and its 400 metre walkable (in five minutes) catchment (Fig. 4), which is regarded as being the distance people generally walk to access everyday amenities (West Australian Planning Commission and Infrastructure 2007). This is also commensurate with the area in which property values could be expected to be uplifted by a park redesign (Lutzenhiser $\mathcal{E}$ Netusil 2001). The intention is that this would be the area that could undergo significant infill development.

\section{The ecological enhancement of urban parks}

In this step, the selected parks are redesigned in order to increase their ecological and social value and, ultimately, to encourage redevelopment and upzoning (Fig. 5). There are several general design interventions that have been suggested to enhance the ecological value of urban parks, as well as improve the experience of nature by urban dwellers. [12] First, parks redesign should use plantings with native species, in a variety of forms and spaces (for example, buffering wetlands, along paths, in garden beds, and in scattered patches resembling native ecosystems). These spaces are important for biodiversity (e.g., McFrederick \& LeBuhn 2006; Koh $\mathcal{E}$ Sodhi 2004) and also for a sense of place, especially in parks where no remnant vegetation is left (Forristal et al. 2012). Importantly, plantings should use species with different flowering periods, forms, textures, and colours, which convey an aesthetic of beauty and care, and also provide a variety of food and habitat resources for wildlife throughout the year. If non-native plants are used, they must not have invasive tendencies, and should have low water and fertilizer requirements. While the use of native plants is highly recommended, these criteria can be softened in regards to non-native trees to be planted in a scattered manner-different trees can have a high aesthetic value and play an important role in the control of sun exposure and temperature regulation (Seddon 2007). Second, while tidy, highly managed areas may be present, redesign interventions can include areas where natural succession in vegetation cover and ecosystem processes is encouraged (Thompson 2002). If remnant vegetation is present, it must be included in this type of management. However, other designed or enhanced habitats, such as wetlands and planted woodlands, can also be managed in this way. Third, large trees should be preserved and managed adequately, as they provide crucial habitat and food resources for birds and other wildlife (Stagoll et al. 2012). Finally, education interventions, including on-site signage and artwork, should be used to promote and strengthen the connection between park users and the local nature and landscape (Gobster et al. 2007; Hunter \& Hunter 2008).

Following these recommendations, we propose that the edges of Hillcrest Park are planted with a diverse palette of suitable native and nonnative trees, native low shrubs, and herbaceous plants, so they assume a more vegetated and diverse appearance, particularly when viewed from surrounding properties. This planting 'armature' following organic, nonrigid lines would swathe a circuitous promenade, as well as a number of smaller spaces designed to allow for an assortment of functions. These spaces would include drainage swales for infiltration and cleansing of stormwater flowing off the adjacent roads, reclusive quiet areas, naturebased play areas, and picnic and $B B Q$ areas. These different areas would increase the opportunities for socialization, contemplation, nature-based and passive recreation, but would also enhance the ecosystem services provided by the park and its ecological value. Also, this 'soft shell' of vegetation would act as a buffer between the proposed active recreation occurring in the central areas of the park and the neighbouring residents, reducing the potential for noise- and sports lighting-related complaints (Lutzenhiser $\&$ Netusil 2001). So as to minimize friction with residents living immediately adjacent, entrances to the park will be concentrated at the street intersections so that park traffic is not directed towards individual residential buildings (Fig. 6).

While the heart of the park is to remain relatively open, it is proposed that the three ovals of Hillcrest Park would be consolidated into one smaller oval, which would be re-turfed with a turf hybrid that allows for greater frequency of sporting and community uses. The consolidation of the oval area is not intended to denigrate the often important social and recreational functions of team sports, but rather to provide a greater number of active and passive recreational pursuits reflective of changing recreational trends in Australia (Australian Bureau of Statistics 2010). Also, ovals located in other urban parks that are not in zones of proposed den- 

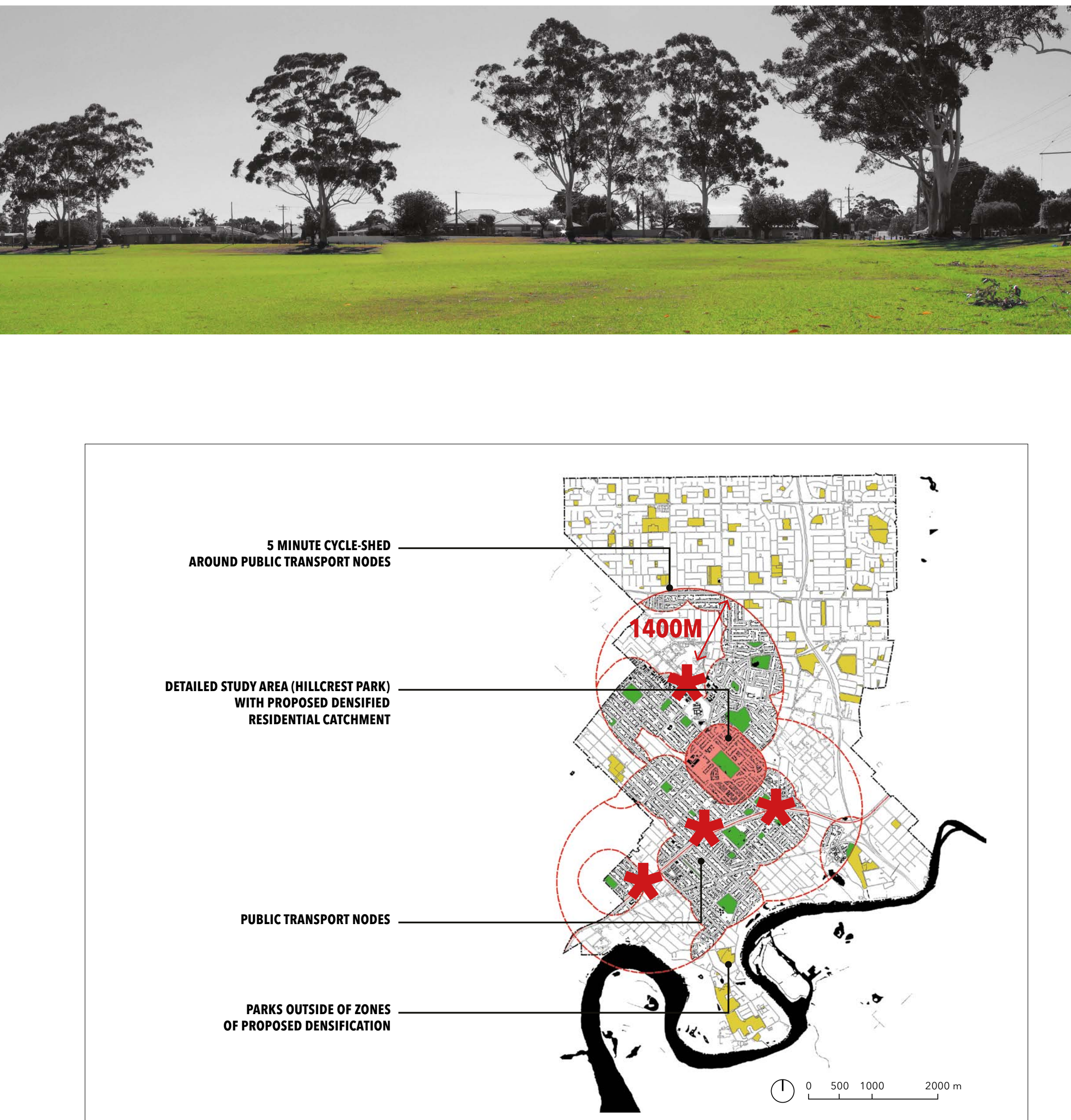

Figure 3 Parks for upgrading and adjacent densification. 


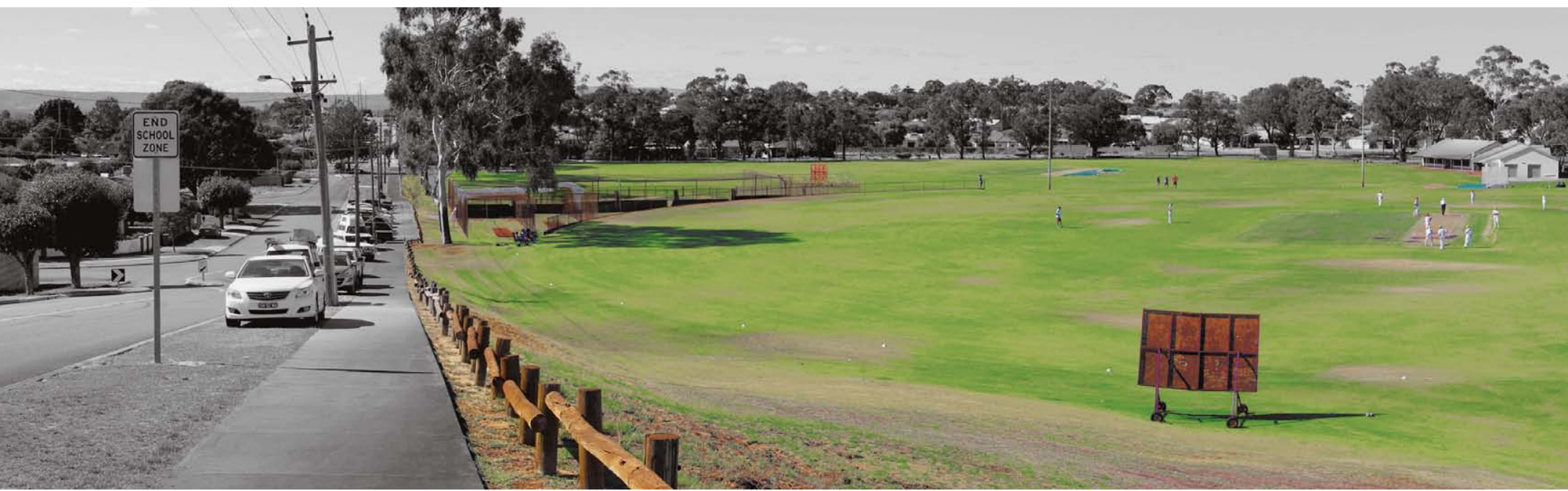

Figure 4 Study area / Hillcrest Park.

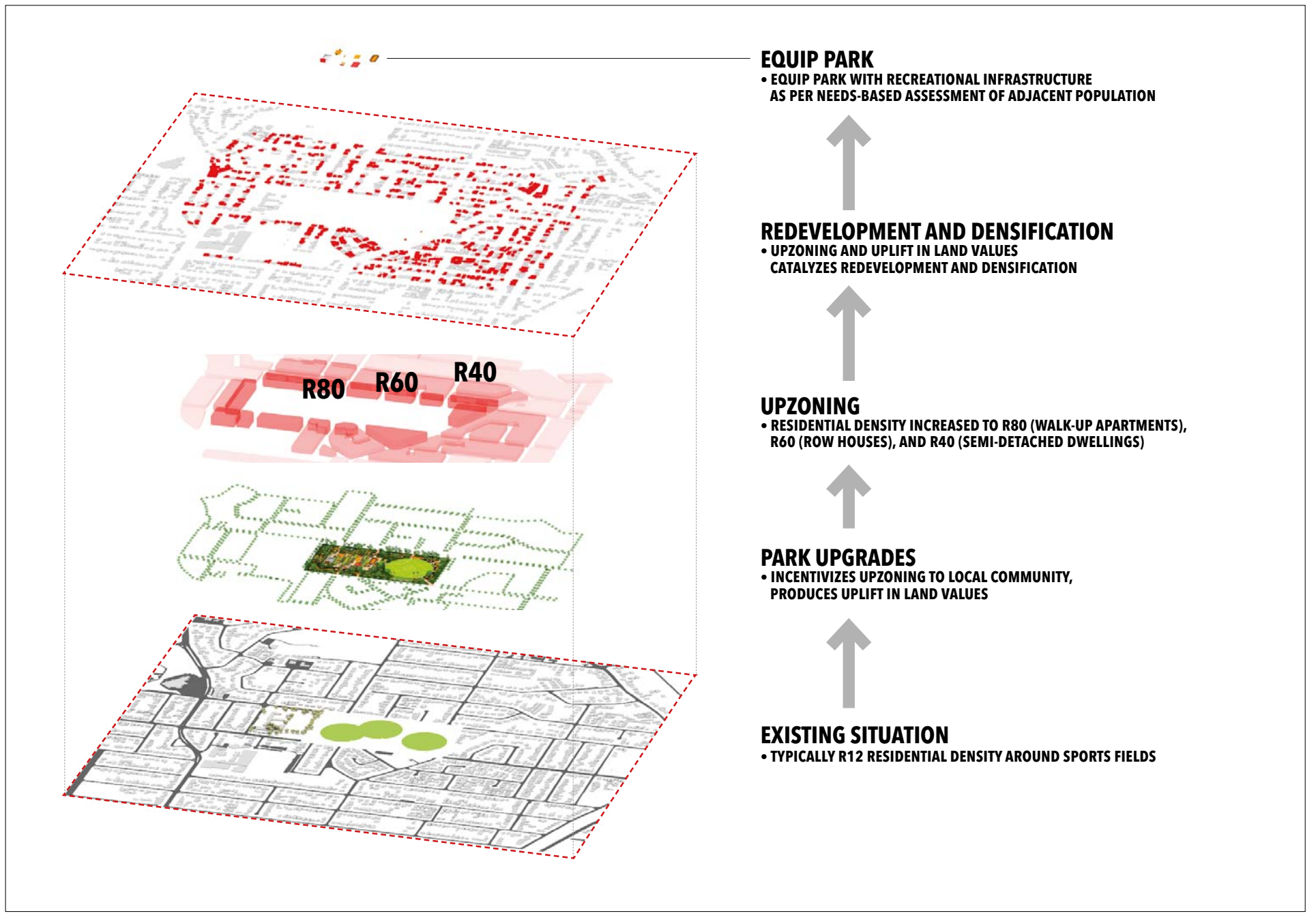

Figure 5 Park redesign. Selected parks are redesigned so as to encourage redevelopment and upzoning. 


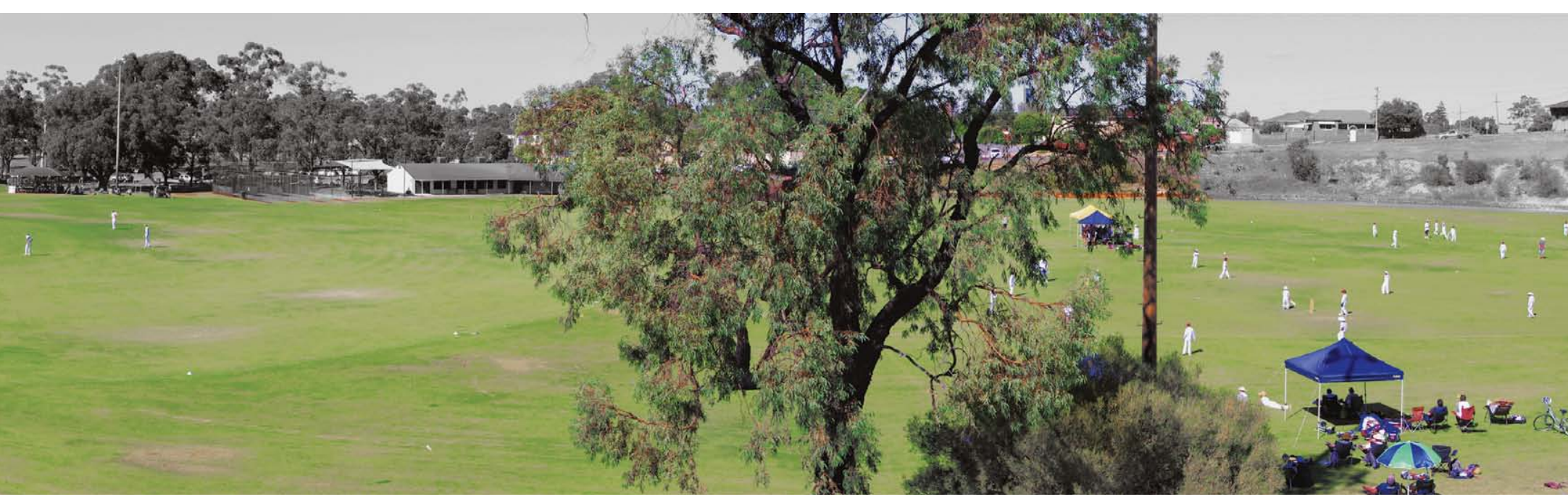

sification could specifically cater for active sports practice and events (Fig. 3). The area freed up by the consolidated ovals would be a flexible 'loose fit' space (Franck \& Stevens 2007; Thompson 2002), allowing for a variety of functions developed in relation to shifting community preferences, which would be established after significant residential densification has occurred; this is discussed in step 4.

\section{Upzoning}

In this step, the five minute walkable park catchment is upzoned. In the case of Hillcrest Park, it is proposed that the rezoning is done in three different zones: $\mathrm{R} 40$ (40 dwellings per hectare) in the zone furthest from the park, R6o, and then R8o in the zone immediately adjacent to the park (Fig. 5). These zoning densities correlate to semi-detached dwellings, row houses, and low rise apartments, respectively (Kellet $\&$ Rofe 2009). [13] If the zoning densities were achieved, then the total population of the study area would increase from 2,140 to around 7,400 people, roughly commensurate with the local government area's infill dwelling target for 2031.

\section{A needs-based assessment and equip park}

In this step, after significant densification (roughly greater than 50 percent) has occurred in the park catchment, it is intended that the 'loose fit' park space is equipped to provide the required recreational amenity to the surrounding community. At this point, a needs-based assessment would be conducted to establish the recreational equipment required to activate the park-required because, as Sipe and Byrne (2010) describe, when we look in more detail at who resides in townhouses, mid-rise, and high-rise apartments in Australia, we find that 'there is no typical higher density resident'. Indeed, research shows that higher density residents are widely varied, differing by age, income, race / ethnicity, household composition, family status, and the like (Sipe $\mathcal{E}$ Byrne 2010). As such, the question of the appropriate equipment that should be provided for a higher density population can only be answered by a needs-based assessment, carried out when densification has occurred to a significant degree.

Effective public open space should not be designed for a single physical activity, but rather should cater for a diverse range of activities and uses (Kellet $\&$ Rofe 2009). These uses could include skate-able spaces, informal BMX areas (not a full competition BMX track), basketball and netball rings, soccer goals and spaces (not a whole field), innovative play areas, fitness equipment, enclosed dog exercise areas, $\mathrm{BBQ}$ areas, picnic settings, community markets, and community gardens (Suter Planners 2011). These uses add to the typical organized team sports set-ups, provided by the retained oval, and to the more passive recreational nature-oriented uses (for example, nature observation and interpretation, and contemplation), permitted by the ecological approach applied to the park redesign.

Beyond the provision of recreational equipment, the design of the space itself needs to provide a significant degree of flexibility. To this end, researchers have identified the possibilities of 'loose spaces', which 'offer a freedom of choice of activities and more means of carrying them out', by being open to appropriation (Franck \& Stevens 2007). This programmatic indeterminacy is not to be confused with openness, which limits activities to those that can be carried out in a void. Flexibility of use can actually be constrained by overly 'open' space, but also by overdesign in which an 'emphasis on static, visual qualities of space does not in fact make for loose and free use of space, but one where use is highly controlled and limited' (Ward Thompson 2002). [14] What is suggested is that a balance needs to be achieved so as to provide the necessary infrastructure and spaces for the park to be open to appropriation by users, but not overdesigned to the point that the park begins to constrain usage.

While Perth's greyfield parks have typically privileged the 'public' over the insertion of 'privatized' functions, it is intended that in this step a private café, or something similar, could be included so as to provide a further stream of revenue for the upgrading and maintenance of the park; this could be incorporated into the club and change rooms facilities required to support sporting use (Sipe $\mathcal{E}$ Byrne 2010). [15]

\section{Conclusion}

Arguably, the significance of this research extends to both the way in which infill development in Perth is strategized and to the nature of public open space in greyfield suburbs. With respect to the former, the significance of this research is that if the proposed approach was to be successfully applied across greyfield settings in Perth, this could yield a significant number of infill dwellings. [16] Figure 7 shows proposed densification around greyfield parks larger than 1 hectare and within a five minute bicycle ride, or a twenty minute walk from train stations; thereby potentially offering both amenity (via redesigned public open space) and connectivity (via train stations) for future residents (Fig. 7). Hypothetical- 


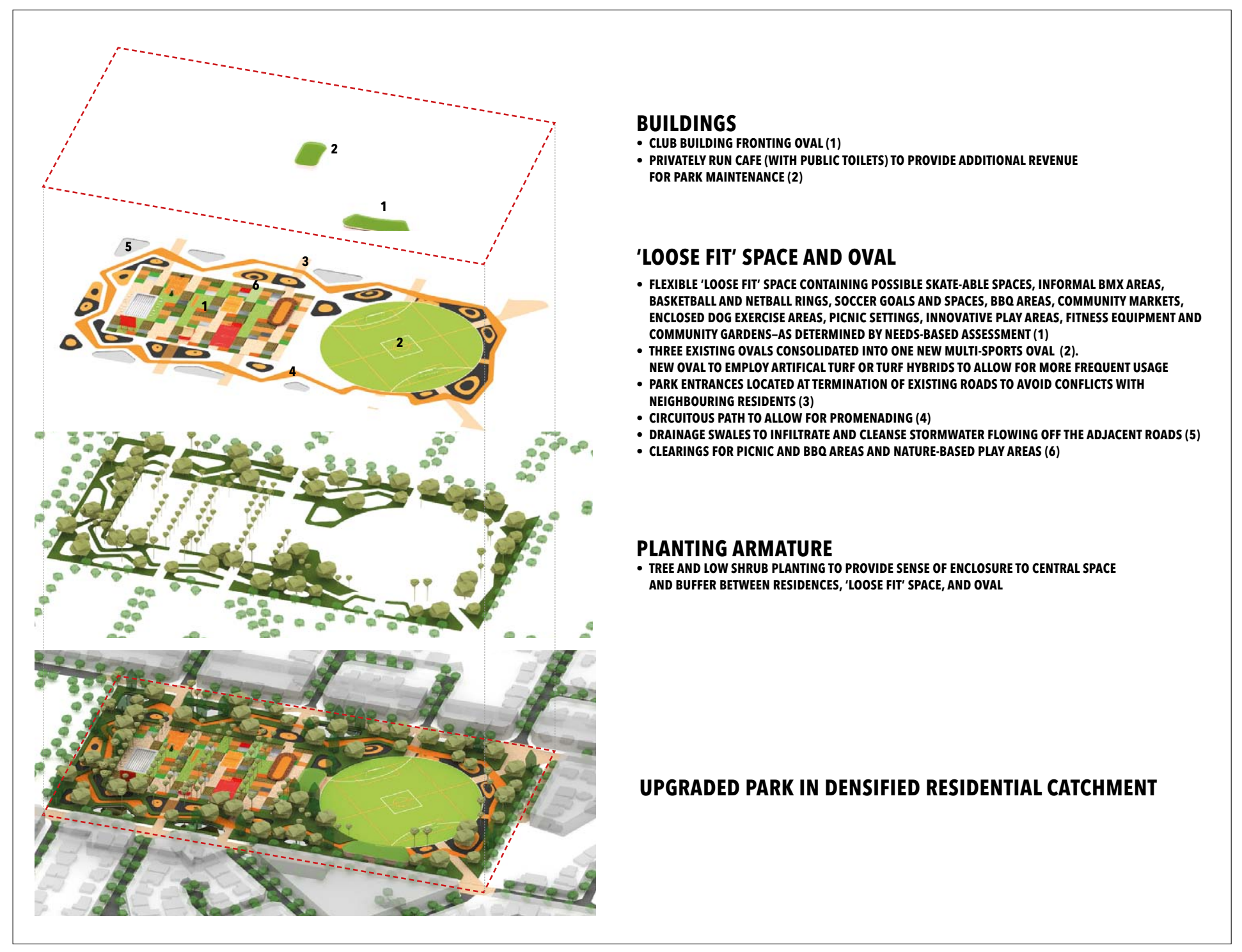

Figure 6 Detailed park redesigns. Selected parks are redesigned to increase their ecological and social value and support the demands of an adjacent residential community increasing in size.

ly, if the residential lots (shown in orange) were redeveloped at a comparatively low density of $\mathrm{R} 40$, using the proposed process, then about 170,000 dwellings could be accommodated. While, given the patchiness of development conditions, this is an unlikely outcome, even if only a fraction of these lots were redeveloped, this could make a significant contribution towards the 121,000 infill dwellings that are targeted in Perth's planning document 'Directions 2031' (Western Australian Department of Planning 2010). If the ecologically enhanced parks were connected by well-treed and vegetated street corridors, they could also begin to form a relatively connected regional ecological network across Perth's greyfield suburbs.

Perth's existing hierarchical classification of parks is defined by the 'Liveable Neighbourhoods Code' (West Australian Planning Commission and Infrastructure 2007), which concerns the provision of public open space in new residential subdivisions, and by the "Classification framework for public open space' (Western Australian Department of Sport and Recreation 2012), which classifies public open space across Perth's established greyfield suburbs. [17] Evidently, the potential role of parks to catalyze and support increased density, as discussed here, is not mentioned in the latter framework. [18] We argue that because Perth's target is that 47 percent of all new development should be infill (Western Australian Department of Planning 2010), a typology of public open space should consider areas of urban consolidation. Simply put, Perth's existing planning for public open space is suburban and what is needed are new types of parks, adapted to denser conditions. While Kellet and Rofe (2009) argue that there is 'no comprehensive justification for the open space standards which have historically been widely applied' in Australia's suburbs, these standards become particularly spurious when applied out of the low density suburban context they have historically served.

Beyond the metrics of metropolitan densification and implications for public open space hierarchies, the strategy described here could have significant positive impacts for residents, in terms of well-being, environmental health and quality of the urban space, as well as the understandings of, and access to, nature. One possible concern of producing residential densification around public transport hubs and corridors, as 


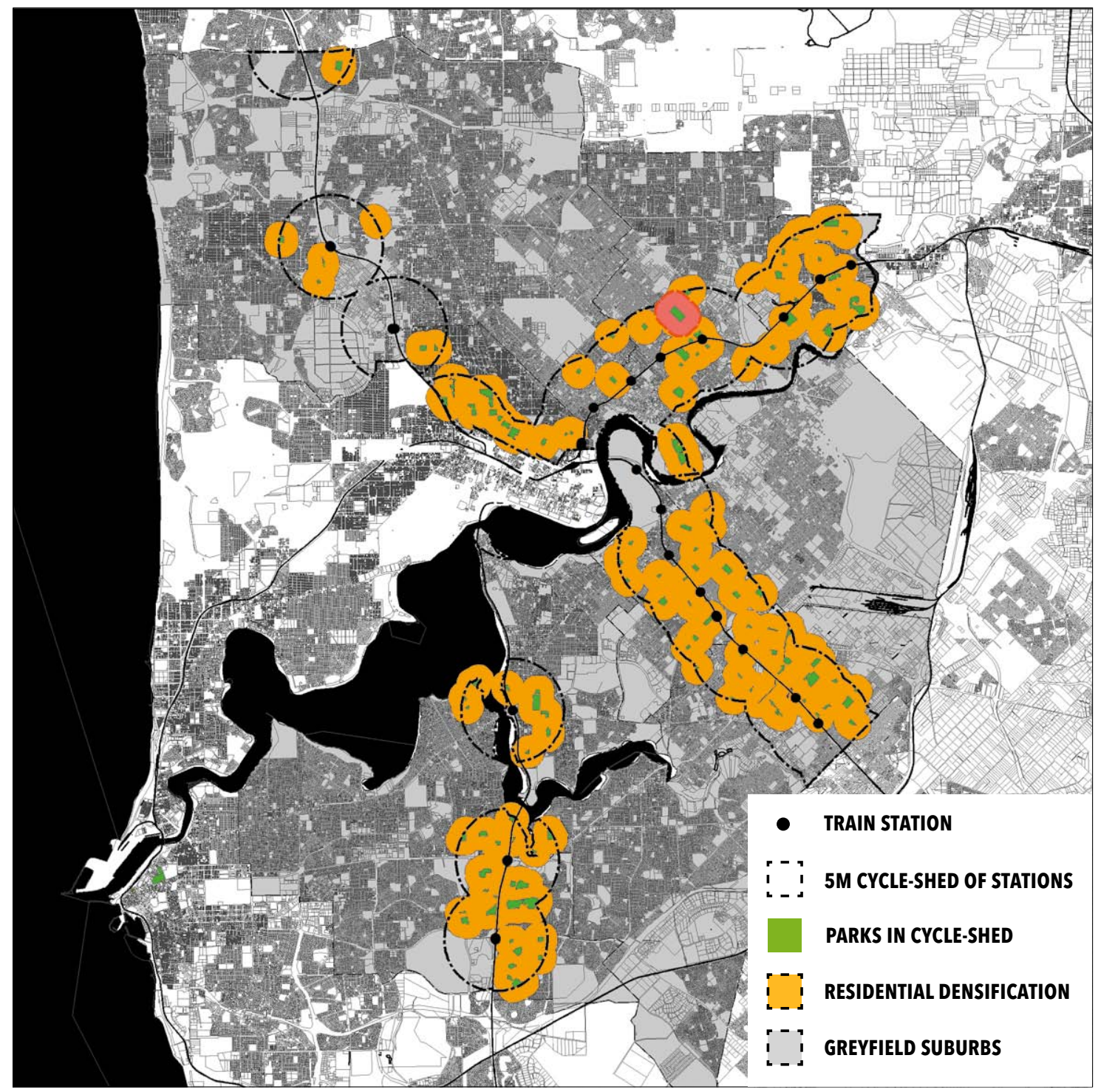

Figure 7 Metropolitan scale potential of the suggested approach.

advocated in Australia's capital city planning documents (Western Australian Department of Planning 2010), is that this densification will occur in a way in which residents have minimal access to 'nature'. If this occurs, it is reasonable to conclude that a collective understanding of, and connection to, the ecology of the Swan Coastal Plain in which Perth is sited, will be further eroded. This is of particular significance for children (Louv 2008) who, unlike Perth's current adult population, will grow up without access to generous backyards, which were fundamental to Perth's suburban idyll in the twentieth century. The redesigned landscape of greyfield parks would likely improve the quality of the urban environment, provide a greater sense of naturalness, and have a greater ability to bring the natural world to urban dwellers' lives. As such, these parks could perform an eco-revelatory function (Helphand \& Melnick 1998), eco-revelatory designs being those that "can punctuate and enliven our environment and sensitize us to what is known about interlocking (ecological) complexities' (Helphand \& Melnick 1998).
This paper has proposed an additional strategy for achieving infill development in Perth's greyfield suburbs but is generalizable to the greyfields of other Australian cities. This strategy in which redesigned public open space is correlated with increased residential densification could create synergies with respect to incentivizing communities to support densification, catalyzing conditions for redevelopment, improving ecological outcomes, and potentially increasing the sense of connection to, and understanding of, nature by higher density residents.

Acknowledgement

The authors would like to acknowledge Richard Weller for his initial idea to link densification with parks in greyfield suburbs, and Dinis Candeias for his assistance with the research. 
1 NIMBY: 'not in my back yard'.

2 In fact, much of the infill development in recent years has been achieved through opportunistic subdivision of individual lots resulting in the loss of the Australian backyard and its replacement with typically unusable residual spaces (Hall 2010).

3 The term naturalness generally describes how close a landscape is to a perceived natural state, in a continuum between natural, intact landscapes (for example, wilderness areas) and non-natural, highly modified landscapes (for example, builtup areas) (Ode et al. 2009; Anderson, 1991).

4 In the North American context, the term 'greyfield land' was originally coined by the Congress for the New Urbanism to describe 'dead malls' and the vast empty asphalt parking lots that surround them. This is not to be confused with the Australian definition used in this paper.

5 We use the term 'nature' here, and generally in the paper, not to evoke 'the pristine nature of wilderness' but the vegetated nature of urban parks and gardens, which results from the combination of remnant vegetation or individual remnant plants (for example, trees) and planted native and non-native plant species (Thompson, I. [2011], "Ten Tenets and Six Questions for Landscape Urbanism”, Landscape Research, 37: 7-26).

6 Commissioned by the Western Australian Departments of Housing and Planning.

7 Research into the compensation hypothesis in Perth only extends to fairly low densities, surveying residents in 500 square metres lots or less (Syme, G., Fenton, M., and Coakes, S. [2001], 'Lot Size, Garden Satisfaction and Local Park and Wetland Visitation', Landscape and Urban Planning: 161-170). Presumably, the trends established in this research will be further amplified in even higher density settings.

8 Land tax is calculated on the Unimproved Land Value (ULV), which is assumed to be 30 percent of the residential property's market value (Pracsys [2012], Fremantle Traffic Bridge; Economic and Social Benefit Assessment [Perth: Pracsys]). Council rates are calculated on the Gross Rental Value (GRV) of the property, which is assumed to be 5 percent of the market value (Ibid.). Both of these are expected to increase with a higher density zoning and POS redesigns being introduced. Stamp duty revenue will presumably increase as a greater number of dwellings exist to be bought and sold.

9 This purported unpopularity is evidenced by the significant number of vacant residential lots adjacent to the case study park.

10 Perth has an electrified suburban train system, covering 173 kilometres of track and including twenty-one stations on four principal lines, which run through the study area. Perth has a proposed light rail link, which is to run north from Perth to Mirrabooka. This has been excluded from this exercise because the proposal is still being studied.

11 This strategy is intended to complement other State planning policies, which are in some cases more targeted to these groups. State planning policy in Australia is typically directed towards densification of urban areas within a five minute walk of public transport hubs, a form of densification which may be more appropriate to those requiring even closer access to services provided in such centres.

12 However, this has been recognized as an urgent field of future research (Lin, B. B., Fuller, R. A., Bush, R., Gaston, K. J., and Shanahan, D. F. [2014], 'Opportunity or Orientation? Who Uses
Urban Parks and Why', PLoS ONE 9: e87422; Fuller, R. A., Irvine, K. N., Devine-Wright, P., Warren, P. H., and Gaston, K. J. [2007], 'Psychological Benefits of Greenspace Increase with Biodiversity', Biology Letters 3: 390-394). The exact nature of the building typologies of this urban densification is indicative, and is not a direct part of the scope of this paper.

13 This is particularly true for children. While the literature and guidelines often focus on more structured features of parks and open space (such as playground equipment and paths) from a broader child development perspective, opportunities for creative play, exploring, make-believe, contact with different textures, and exposure to nature are all critical and often missing in the more typical 'plastic fantastic' playgrounds of today (Wood, L. [2008], Action for Young Australians Report: Parks and Open Space for Health and Well-Being of Children and Young People [Canberra: The Australian Research Alliance for Children and Youth]).

14 Such community facilities provide a good location also for adjoining public toilets. (Suter Planners [2011], Principles and Guidelines: Best Practice Open Space in Higher Density Developments Project [Adelaide: City of Charles Sturt]).

15 Indeed, given the similarity of greyfield conditions across Australia's capital cities, this approach is potentially generalizable to the national context.

16 The DSR's hierarchy of POS includes Pocket Open Space (0-0.399 hectare), Local Open Space (0.4-0.999 hectare), Neighbourhood Open Space (1.0-4.999 hectares), District Open Space (5.0-19.999 hectares), and Regional Open Space (,20 hectares). These classifications are intended as a starting point to develop an understanding of the general function and catchment of POS.

17 This is part of a wider issue that there is a paucity of evidence in respect of the appropriate provision or design of open space in higher density and transit-oriented developments (Kellet, J. and Rofe, M. [2009], Creating Active Communities: How Can Open and Public Spaces in Urban and Suburban Environments Support Active Living? (Adelaide: Institute for Sustainable Systems and Technologies, University of South Australia).

18 While the Western Australian Department of Planning is pursuing 'activity centres' as being the main device for achieving residential densification, our GIS analysis indicates that their selected 'activity centre' sites currently only contain 2.64 percent parkland. While these 'activity centres' will undoubtedly see the development of more POS as the centres themselves are constructed, the degree to which residents will be able to directly access 'natural' landscapes is questionable.

\section{References}

Anderson, J. E. (1991), 'A Conceptual Framework for Evaluating and Quantifying Naturalness', Conservation Biology 5: 347-352.

Australian Bureau of Statistics (2010), Participation in Sport and Physical Recreation (Canberra: Australian Bureau of Statistics).

Australian Bureau of Statistics (2011), Population Projections, Australia, 2006 to 2101, (Canberra: Australian Bureau of Statistics) [website], www.abs.gov.au/Ausstats/abs@.nsf/mf/3222.0, accessed 9 February 2011

Bento, A. M., Cropper, M. L., Mobarak, A. M., and Vinha, K. (2005), 'The Effects of Urban Spatial Structure on Travel Demand in the United States', Review of Economics and Statistics 87: 466-478.
Bolund, P. and Hunhammar, S. (1999), ‘Ecosystem Services in Urban Areas', Ecological Economics 29: 293-301.

Brownstone, D. and Golob, T. F. (2009), ‘The Impact of Residential Density on Vehicle Usage and Energy Consumption', Journal of Urban Economics 65: 91-98.

Calthorpe, P. and Fulton, W. (2001), The Regional City (Washington, DC: Island Press).

Centre for the Built Environment and Health (2013), Public Open Space (POS) Geographic Information System (GIS) Layer (Perth: University of Western Australia) [website], http://researchdata.ands.org.au/public-open-space-pos-geographic-information-system-gis-layer, accessed 11 June 2013

Chiesura, A. (2004), 'The Role of Urban Parks for the Sustainable City', Landscape and Urban Planning 68: 129-138.

City of Melbourne (2010), Transforming Australian Cities for a More Financially Viable and Sustainable Future (Melbourne: City of Melbourne).

Coley, R. L., Sullivan, W. C., and Kuo, F. E. (1997), 'Where Does Community Grow? The Social Context Created by Nature in Urban Public Housing', Environment and Behavior 29: 468-494.

Crompton, J. (2005), 'The Impact of Parks on Property Values: Empirical Evidence from the Past Two Decades in the United States', Managing Leisure 10: 203-218.

Curtin University Business School and Hames Sharley (2013), The Housing We'd Choose: A Study for Perth and Peel (Perth: Perth Department of Housing, Department of Planning).

Dallimer, M., Irvine, K. N., Skinner, A. M. J., Davies, Z. G., Rouquette, J. R., Maltby, L. L., Warren, P. H., Armsworth, P. R., and Gaston, K. J. (2012), 'Biodiversity and The Feel-Good Factor: Understanding Associations Between Self-Reported Human Well-Being and Species Richness', Bioscience 62: 47-55.

Dodson, J. and Sipe, N. (2008), Unsettling Suburbia: The New Landscape of Oil and Mortgage Vulnerabilty in Australian Cities (Brisbane: Griffith University).

Duckworth-Smith, A. (2009), 'The Path of Density', in R. Weller (ed.), Boomtown (Perth: University of Western Australia Publishing).

Duckworth-Smith, A. (2012), Mean Streets: Residential Intensification Strategies for the Sprawled City (Perth: University of Western Australia).

Dunn, R. R., Gavin, M. C., Sanchez, M. C., and Solomon, J. N. (2006), 'The Pigeon Paradox: Dependence of Global Conservation on Urban Nature', Conservation Biology, 20: 1814-1816.

Forristal, L. J., Lehto, X. Y., and Lee, G. (2012),

'The Contribution of Native Species to Sense of Place', Current Issues in Tourism: 1-20.

Franck, K. and Stevens, Q. (eds.) (2007), Loose Space: Possibility and Diversity in Urban Life (London: Routledge).

Fuller, R. A., Irvine, K. N., Devine-Wright, P., Warren, P. H., and Gaston, K. J. (2007), 'Psychological Benefits of Greenspace Increase with Biodiversity', Biology Letters 3: 390-394.

Gobster, P., Nassauer, J., Daniel, T., and Fry, G. (2007), 'The Shared Landscape: What Does Aesthetics Have to do with Ecology?', Landscape Ecology 22: 959-972.

Gobster, P. H. (2001), 'Visions of Nature: Conflict and Compatibility in Urban Park Restoration', Landscape and Urban Planning 56: 35-51. 
Grose, M. (2010), 'Turf That Works: Changing Turf in Perth's Public Open Spaces', in D. Nichols, A. Hurlimann, and C. Mouat (eds.), Tenth Urban Biennial History / Planning History (UHPH) Conference, 2010 (Melbourne: The University of Melbourne).

Hall, T. (2010), The Life and Death of the Australian Backyard (Collingwood, Victoria: CSIRO Publishing).

Helphand, K. and Melnick, R. (1998), 'Eco-Revalatory Design: Nature Constructed / Nature Revealed', Landscape Journal: x-xi.

Humpel, N., Owen, N., and Leslie, E. (2002), 'Environmental Factors Associated with Adults' Participation in Physical Activity: A Review', American Journal of Preventive Medicine 22: 188-199.

Hunter, M. R. and Hunter, M. D. (2008), 'Designing for Conservation of Insects in the Built Environment', Insect Conservation and Diversity 1: 189-196.

Jim, C. Y. and Chen, W. Y. (2009), 'Ecosystem Services and Valuation of Urban Forests in China', Cities 26: 187-194.

Kellet, J. and Rofe, M. (2009), Creating Active Communities: How Can Open and Public Spaces in Urban and Suburban Environments Support Active Living? (Adelaide: Institute for Sustainable Systems and Technologies, University of South Australia).

Kelly, J. F., Breadon, P., and Reichl, J. (2011), Getting the Housing We Want (Melbourne: Grattan Institute).

Keniger, L., Gaston, K., Irvine, K., and Fuller, R. (2013), 'What Are the Benefits of Interacting with Nature?', International Journal of Environmental Research and Public Health 10: 913-935.

Koh, L. P. and Sodhi, N. S. (2004), 'Importance of Reserves, Fragments, and Parks for Butterfly Conservation in a Tropical Urban Landscape', Ecological Applications 14: 1695-1708.

Lin, B. B., Fuller, R. A., Bush, R., Gaston, K. J., and Shanahan, D. F. (2014), 'Opportunity or Orientation? Who Uses Urban Parks and Why', PLoS ONE: 9, e87422.

Louv, R. (2008), Last Child in the Woods. Saving Our Children from Nature-Deficit Disorder (Chapel Hill, NC: Algonquin Books).

Luttik, J. (2000), 'The Value of Trees, Water and Open Space as Reflected by House Prices in the Netherlands', Landscape and Urban Planning 48: 161-167.

Lutzenhiser, M. and Netusil, N. (2001), 'The Effect of Open Spaces on a Home's Sale Price', Contemporary Economic Policy 19: 291-298.

McFrederick, Q. S. and Lebuhn, G. (2006), 'Are Urban Parks Refuges for Bumble Bees Bombus Spp. (Hymenoptera: Apidae)?', Biological Conservation 129: 372-382.

Mead, E., Dodson, J., and Ellway, C. (2006), 'Urban Environments and Health: Identifying Key Relationships and Policy Imperatives', Urban Research Program [Online].

Miller, J. R. (2005), 'Biodiversity Conservation and the Extinction of Experience', Trends in Ecology and Evolution 20: 430-434.

Nechyba, T. J. and Walsh, R. P. (2004), 'Urban sprawl', The Journal of Economic Perspectives 18: 177-200.

Newman, P., Beatley, T., and Boyer, H. (2009), Resilient Cities (Washington, DC: Island Press).

Newton, P., Murray, S., Wakefield, R., Murphy, C., Khor, L. A., and Morgan, T. (2011), Towards a New Development Model for Housing Regeneration in Greyfield Residential Precincts (Swinburne / Monash: Australian Housing and Urban Research Institute).
Newton, P. W. (2010), 'Beyond Greenfield and Brownfield: The Challenge of Regenerating Australia's Greyfield Suburbs', Built Environment 36: 81-104.

Ode, Å., Fry, G., Tveit, M. S., Messager, P., and Miller, D. (2009), 'Indicators of Perceived Naturalness as Drivers of Landscape Preference', Journal of Environmental Management, 90: 375-383.

Pandit, R., Polyakov, M., and Sadler, R. (2013), 'Valuing Public and Private Urban Tree Canopy Cover', Australian Journal of Agricultural and Resource Economics: 453-470.

Pracsys (2012), Fremantle Traffic Bridge; Economic and Social Benefit Assessment (Perth: Pracsys).

Productivity Commission (2011), Performance Benchmarking of Australian Business Regulation: Planning, Zoning and Development Assessments (Canberra: Productivity Commission).

Radeloff, V. C., Stewart, S. I., Hawbaker, T. J., Gimmi, U., Pidgeon, A. M., Flather, C. H., Hammer, R. B., and Helmers, D. P. (2010), 'Housing Growth In and Near United States Protected Areas Limits Their Conservation Value', Proceedings of the National Academy of Sciences 107: 940-945.

Ramalho, C. E., Laliberté, E., Poot, P., and Hobbs, R. J. (2014), 'Complex Effects of Fragmentation on Remnant Woodland Plant Communities of a Rapidly Urbanizing Biodiversity Hotspot', Ecology 95: 2466-2478.

Schneider, A. and Woodcock, C. E. (2008), 'Compact, Dispersed, Fragmented, Extensive? A Comparison of Urban Growth in Twenty-five Global Cities Using Remotely Sensed Data, Pattern Metrics and Census Information', Urban Studies 45, 659-692.

Seddon, G. (2007), The Old Country: Australian Landscapes, Plants and People (Cambridge: Cambridge University Press).

Seto, K. C., Kaufmann, R. K., and Woodcock, C. E. (2000), 'Landsat Reveals China's Farmland Reserves, but They're Vanishing Fast', Nature 406: 121-121.

Sipe, N. and Byrne, J. (2010), Green and Open Space Planning for Urban Consolidation-A Review of the Literature and Best Practice (Brisbane: Griffith University).

Stagoll, K., Lindenmayer, D. B., Knight, E., Fischer, J., and Manning, A. D. (2012), 'Large Trees are Keystone Structures in Urban Parks', Conservation Letters, 5: 115-122.

Sturm, R. and Cohen, D. A. (2004), 'Suburban sprawl and physical and mental health', Public Health 118: 488-496.

Suter Planners (2011), Principles and Guidelines: Best Practice Open Space in Higher Density Developments Project (Adelaide: City of Charles Sturt)

Syme, G., Fenton, M., and Coakes, S. (2001), 'Lot Size, Garden Satisfaction and Local Park and Wetland Visitation', Landscape and Urban Planning: 161-170.

Thompson, C. W. (2002), 'Urban Open Space in the 21st Century', Landscape and Urban Planning 60: 59-72.

Thompson, I. (2011), 'Ten Tenets and Six Questions for Landscape Urbanism', Landscape Research 37:7-26.

Tzoulas, K., Korpela, K., Venn, S., Yli-Pelkonen, V., Kazmierczak, A., Niemela, J., and James, P. (2007), 'Promoting Ecosystem and Human Health in Urban Areas Using Green Infrastructure: A Literature Review', Landscape and Urban Planning 81: 167-178.

Ulrich, R. (1984), 'View Through a Window May Influence Recovery From Surgery', Science 224: 420-421.
Uzzell, D., Pol, E., and Badenas, D. (2002), 'Place Identification, Social Cohesion, and Environmental Sustainability', Environment and Behavior 34, 26-53.

Ward Thompson, C. (2002), 'Urban Open Space in the 21st Century', Landscape and Urban Planning 60, 59-72.

West Australian Planning Commission and Western Australian Department of Planning and Infrastructure (eds.) (2007), Liveable Neighbourhoods; a Western Australian Government Sustainable Cities Initiative (Perth: West Australian Planning Commission).

Western Australian Department of Sport and Recreation (2012), Classification Framework for Public Open Space (Perth: Department of Sport and Recreation).

Western Australian Department of Planning (2010), Directions 2031 and Beyond: Metropolitan Planning Beyond the Horizon (Perth: Department of Planning).

Wong, T. (2006), 'Water Sensitive Urban Design-the Journey Thus Far', Australian Journal of Water Resources 1 10/3: 213-222.

Wood, L. (2008), Action for Young Australians Report: Parks and Open Space for Health and Well-Being of Children and Young People (Canberra: The Australian Research Alliance for Children and Youth).

Woodcock, I., Dovey, K., Wollan, S., and Beyerle, A. (2010), 'Modelling the Compact City; Capacities and Visions for Melbourne', Australian Planner 47: 94-104.

Zhao, Z. and Kaestner, R. (2010), 'Effects of Urban Sprawl on Obesity', Journal of Health Economics 29: 779-787.

\section{Biographical notes}

Julian Bolleter is an Assistant Professor at the Australian Urban Design Research Centre (AUDRC), at the Faculty of Architecture, Landscape Architecture and Visual Arts, The University of Western Australia. His role at the AUDRC includes teaching a Master's programme in urban design and conducting urban design research and design projects.

Cristina E. Ramalho is an ecologist and an affiliated researcher at the AUDRC. She has a particular interest in urban ecology, namely in understanding the landscape planning and design strategies that are required to retain and enhance native biodiversity in cities.

Contact

\section{Julian Bolleter}

Australian Urban Design Research Centre

Faculty of Architecture, Landscape Architecture

and Visual Arts

The University of Western Australia

Level 2, 1002 Hay Street

Perth, WA 6000, Australia

Phone: +61863186203

julian.bolleter@uwa.edu.au

\section{Cristina E. Ramalho}

Australian Urban Design Research Centre

Faculty of Architecture, Landscape Architecture

and Visual Arts

The University of Western Australia

Level 2, 1002 Hay Street

Perth, WA 6000, Australia cristina.e.ramalho@gmail.com 